\title{
STUDI POTENSI KOMPETISI ANTARA PASAR TRADISIONAL DENGAN TOKO MODERN PASCA PERATURAN PRESIDEN (PERPRES) NOMOR 112 TAHUN 2007 DI MADURA*
}

\author{
Uswatun Hasanah dan Indien Winarwati \\ Fakultas Hukum Universitas Trunojoyo \\ E-mail: al_uswa@yahoo.co.id
}

\begin{abstract}
The presence of Regulation the President No. 112 of 2007 is expected to realize the presence of a modern store that can compete in a healthy and fair with traditional markets. Although it has been mentioned that the establishment of modern stores have to pay attention spatial plan district, does not detract from the fact zoning violations on the establishment of a modern store. The study was based on indepth interviews with informants, traditional markets, modern store merchants, officials in the region Bangkalan, Sampang, Pamekasan, Sumenep.The results of this study can be concluded that the competition between the traditional market with modern stores after the enactment of Regulation the Presidential No.112 of 2007 increasingly stringent, as evidenced by the increasing proliferation of modern stores, especially the mini-sale systems and types of merchandise similar to the traditional markets. The factors that became the driving and inhibiting competition is no regulation and management matters. Efforts are being made in overcoming the constraints of competition through improved physical infrastructure, but have not touched on the professionalism of the management of traditional markets.
\end{abstract}

Key words : competition, traditional market, modern store after the enactment Regulation the President No. 112 of 2007

\begin{abstract}
Abstrak
Kelahiran Perpres 112 Tahun 2007 diharapkan dapat mewujudkan kehadiran toko modern yang dapat bersaing secara sehat dan adil dengan pasar tradisional. Meski telah disebutkan pendirian toko modern harus memperhatikan Rencana Tata Ruang Wilayah (RTRW) Kabupaten, tidak mengurangi fakta terjadinya pelanggaran zonasi pendirian toko modern. Penelitian ini didasarkan pada wawancara mendalam dengan informan, pedagang pasar tradisional, pedagang toko modern, pejabat terkait di wilayah Kabupaten Bangkalan, Sampang, Pamekasan, Sumenep. Hasil penelitian menyimpulkan kompetisi antara pasar tradisional dengan toko modern pasca Perpres No.112 Tahun 2007 semakin ketat, dengan meningkatnya jumlah toko modern minimarket yang sistem penjualan dan jenis barang dagangannya sama dengan pasar tradisional. Faktor yang menjadi pendorong dan penghambat kompetisi adalah tiadanya legislasi daerah dan aspek manajemen. Upaya yang telah dilakukan dalam mengatasi kendala kompetisi melalui peningkatan sarana dan prasarana fisik, namun belum menyentuh pada sisi profesionalitas pengelolaan pasar tradisional.
\end{abstract}

Kata kunci: kompetisi, pasar tradisional, toko modern Pasca Perpres No.112 Tahun 2007

\section{Pendahuluan}

Menjamurnya pasar modern dengan keanekaragaman produk-produk yang ditawarkan dan kenyamanan dalam berbelanja membawa implikasi bagi eksistensi pasar tradisional yang

- Penelitian ini dilaksanakan atas biaya DIPA Dikti DP2M 2011 Dirjen Dikti Kemendiknas dengan nomor kontrak: 198. o/ H46. 2/ PL/ 2011 tanggal 30 Mei 2011 notabene kondisinya lebih tertinggal baik dari segi fisik maupun manajemen seperti kenyamanan, keamanan, dan kebersihannya dibandingkan toko modern. Kondisi ini juga ditunjang fenomena jarak yang berdekatan, bahkan bersebelahan antara pasar tradisional dengan toko modern, sehingga semakin meningkatkan kompetisi di antara pasar tersebut yang pada 
gilirannya akan lebih memarjinalkan dan akhirnya berpotensi mematikan pasar tradisional.

Kebijakan liberalisasi pasar perdagangan eceran (ritel) di Indonesia sejak ditandatanganinya Letter of Intent (Lol) antara pemerintah Indonesia dengan Dana Moneter Internasional (IMF) tahun 1998, yang salah satu hasil Lol adalah memberikan kebebasan kepada invest-tor asing masuk ke industri ritel. Hal ini kemudian ditindaklanjuti dengan dikeluarkan-nya Keppres No. 99/1998 dan SK Menteri Investasi No.29/ SK/ 1998. Liberalisasi selanjutnya semakin mendapat tempat dengan dikeluarkannya UU Penanaman Modal No. 25 Tahun 2007 dan UU Perseroan Terbatas No. 40 Tahun 2007 yang lebih memberikan asing untuk dapat membuka usaha ritel di seluruh Indonesia. Hal ini berlmplikasi bahwa kompetisi semakin kompleks, tidak hanya kompetisi antara peritel Indonesia dengan peritel asing, tetapi juga antara peritel Indonesia yaitu antara peritel modern dengan peritel tradisional. Penempatan pedagang ritel modern dengan pedagang tradisional tidaklah tepat, karena yang menjadi persoalan adalah peritel modern ada dan mengambil bagian dari kehidupan pasar tradisional, sasaran pembeli pasar tradisional juga dibidik oleh pasar ritel modern. ${ }^{1}$ Peritel tradisional di Indonesia saat ini telah berjumlah 12,6 juta pedagang pasar tradisional yang terdiri dari pedagang kecil dan lemah modal ${ }^{2}$. Struktur pasar ritel saat ini tetap dikuasai oleh mereka yang mempunyai kemampuan modal dan jaringan distribusi yang luas, apalagi dengan dibukanya kesempatan bagi peritel asing untuk berinvestasi di Indonesia.

Konsideran Undang-undang No. 5 Tahun 1999 tentang Larangan Praktik Monopoli dan Persaingan Usaha Tidak Sehat (selanjutnya disebut UU Anti Monopoli) menghendaki adanya kesempatan yang sama bagi setiap warga negara untuk berpartisipasi di dalam proses produksi dan pemasaran barang dan atau jasa,

Dedie S. Martadisastra, "Persaingan Usaha Ritel Modern dan Dampaknya Terhadap Perdagangan Ritel Tradisional", J urnal Persaingan Usaha, Vol. 4, Tahun 2010, J akarta: KPPU, hlm. 76.

Ali Jusmono, "Persaingan Usaha Pasar Ritel Di Indonesia: Siapa Yang menang", Jurnal Hukum Bisnis, Vol. 27 No. 1, Tahun 2008, J akarta: Fakultas Hukum Unika Atma Jaya, hlm. 4 dalam iklim usaha yang sehat, efektif, dan efisien, sehingga dapat mendorong pertumbuhan ekonomi dan bekerjanya ekonomi pasar yang wajar. Persoalannya di dalam kompetisi pasar ritel, kedudukan partisipan berlapis-lapis, mulai dari pelaku usaha besar, menengah, kecil, bahkan mikro. Stratifikasi pelaku usaha yang seperti ini tentunya membutuhkan perlindungan hukum yang proporsional dengan kedudukannya. Oleh karena itu, ketentuan mengenai zonasi bagi pelaku usaha seperti hypermarket, supermarket, minimarket, dan pengecer kecil menjadi urgen.

Peraturan Presiden No 112 Tahun 2007 tentang Penataan dan Pembinaan Pasar Tradisional, Pusat Perbelanjaan dan Toko Modern (selanjutnya disebut Perpres No. 112 Tahun 2007) merupakan aturan main bagi pelaku usaha di bidang perdagangan antara pedagang tradisional dengan toko modern agar pasar tradisional dapat bersaing dengan pasar modern melalui pengaturan zonasi tentang lokasi pendirian pusat perbelanjaan diwajibkan mengacu pada Rencana Tata Ruang Wilayah (RTRW) Kabupaten. Berkaitan itu, penting dilakukan penelitian tentang potensi kompetisi antara pasar tradisional dengan toko modern pasca diterbitkannya Perpres tersebut.

\section{Permasalahan}

Berdasarkan latar belakang tersebut, penulis tertarik untuk membahas beberapa hal. Pertama, mengenai kompetisi antara pasar tradisional dengan toko modern pasca Peraturan Presiden (Perpres) No. 112 Tahun 2007 di Madura; kedua, mengenai faktor yang menjadi pendo-rong dan penghambat kompetisi antara pasar tradisional dengan toko modern; dan ketiga, mengenai upaya yang dilakukan dalam mengatasi kendala kompetisi antara pasar tradisional dengan toko modern di Madura.

\section{Metode Penelitian}

Penelitian ini merupakan penelitian kualitatif deskriptif. Penelitian dilaksanakan mulai Maret sampai dengan Desember 2011, dengan lokasi penelitian terdiri dari 4 (empat) kabupaten di Madura. Penelitian ini dilakukan di Madu- 
ra, dengan pertimbangan bahwa dengan adanya pembangunan jembatan Suramadu, memunculkan potensi bagi Madura sebagai wilayah alternatif bagi investor di bidang perdagangan khususnya retail. Selain itu, penelitian tentang potensi kompetisi di Madura sepanjang pengetahuan peneliti belum pernah dilakukan sehingga orisinalitas penelitian menjadi bahan pertimbangan.

Informan dipilih berdasarkan informasi dari informan terdahulu. Informan dipilih dengan menggunakan model snowball sampling yaitu menemukan informan dari keteranganketerangan yang diberikan oleh informan sebelumnya. Informasi tentang kompetisi antara pasar tradisional dengan toko modern pasca Perpres No.112 Tahun 2007 diperoleh melalui observasi atau pengamatan terlibat (participan observer) dan wawancara mendalam (in-dept interview) dengan pengelola pasar tradisional, toko modern dan pejabat terkait sebagai informan, serta studi dokumen atas regulasi dan legislasi daerah yang berkaitan dengan pasar tradisional dan toko modern. Data yang diperoleh dianalisis dengan menggunakan tiga jalur kegiatan yakni mereduksi data, menguji data, dan menarik kesimpulan.

\section{Pembahasan \\ Kompetisi antara Pasar Tradisional dengan Toko Modern Pasca Peraturan Presiden (Per- pres) No.112 Tahun 2007 di Madura}

Berdasarkan data yang diperoleh, sejak pembangunan jembatan Suramadu Agustus Tahun 2003 sampai peresmiannya 10 Juni 2009, terjadi peningkatan jumlah toko modern di Madura. Data di Disperindag Kabupaten se Madura, menunjukan bahwa Indomaret menempati posisi pertama dalam ekspansi pendirian seluruh toko modern di Madura sebanyak 35 gerai $(46,67 \%)$, yang diikuti oleh Alfamart 16 gerai $(21,33 \%)$ dan Sidogiri 2 gerai $(2,33 \%$, sisanya merupakan minimarket dan supermarket lokal. Hal ini merupakan cerminan posisi Indomaret di tingkat Indonesia, karena Indomaret dan Alfamart termasuk 10 ritel inti menguasai $83,8 \%$ omset ritel modern Indonesia ${ }^{3}$. Keadaan tersebut memungkinkan untuk terjadinya perkembangan dan peningkatan jumlah toko modern di Madura pada masa mendatang.

Berdasarkan pengamatan, tidak sedikit pendirian toko modern tersebut berdekatan dengan pasar tradisional khususnya di Bangkalan. Para pedagang yang lokasinya berdekatan dengan toko modern merasakan dampak adanya pendirian toko modern. Terutama pedagang yang menjual barang yang pasokannya berasal dari industri/pabrikan, merasakan adanya penurunan pengunjung dan omsetnya menurun, sedangkan pedagang yang hanya menjual barang mentah atau produk pertanian atau industri desa cenderung tidak separah seperti pedagang sebelumnya. Penelitian Awan Santoso di Yogyakarta menunjukkan penurunan omset penjualan yang dialami pedagang pasar tradisional yang menjual produk pabrikan sebesar $34 \%$ yang menjual produk pabrikan dan desa sebesar $18 \%$ yang menjual produk impor $3 \%$ yang menjual produk desa sebesar $45 \%{ }^{4}$ Adapun hasil penelitian AC Nielson, secara makro menyebutkan kehadiran pasar modern telah mengancam eksistensi pasar tradisional dengan meningkatnya pertumbuhan bagi pasar modern sebesar $31,4 \%$ sedangkan pasar tradisional telah tumbuh secara negatif sebesar $8 \%{ }^{5}$ Verdasarkan jumlah, komposisi jumlah pasar tradisional di Madura lebih banyak yaitu 106 pasar terdiri dari pasar tradisional yang ada di kota dan kecamatan, sedangkan toko modern sebanyak 75 gerai seperti terlihat pada tabel 1 .

Terdapat fakta menarik yang terjadi di Kabupaten Sumenep, khususnya Pasar Batuputih yang "mati suri" karena munculnya tokotoko kelontong di sekitar pemukiman masyarakat yang telah dapat menyuplai kebutuhan masyarakat. Berdasarkan pengamatan, diperoleh

\footnotetext{
Awan Santosa \& Puthut Indroyono, 11 Maret, Pedagang Pasar Tradisional Terancam, tersedia di website http: / www. ekonomirakyat.org/ artikel. php?j d=13 diakses 11 Nopember 2011 lbid.

Anonim, "Penelitian Dampak Keberadaan Pasar Mo-dern (Supermarket dan Hypermarket) Terhadap Usaha Ritel Koperasi/Waserda dan Pasar Tradisional", Jurnal Pengkajian Koperasi dan UKM, Vol. 1 No. 1, Tahun 2006, Jakarta: Jakarta: Deputi Bidang Pengkajian Sumberdaya UKMK hlm. 97.
} 
fakta bahwa jarak antara rumah dengan pasar agak jauh sehingga masyarakat enggan ke pasar dan masyarakat lebih suka berbelanja di tokotoko yang lebih dekat dengan tempat tinggal mereka dan yang menyediakan segala kebutuhan harian mereka. Fenomena ini merupakan fakta bahwa sebuah pasar bisa mati karena adanya toko-toko kelontong masyarakat dan yang mengelola itu adalah masyarakat sekitar, sehingga dapat diprediksi apabila toko-toko itu berbentuk toko modern bemodal kuat maka jumlah pasar tradisional yang "mati suri" tentu semakin meningkat.

\section{Tabel 1 : J umlah Pasar Tradisional dan Toko Modern}

\begin{tabular}{|c|c|c|c|}
\hline No. & Kabupaten & $\begin{array}{c}\text { J umlah } \\
\text { Pasar } \\
\text { Tradisional }\end{array}$ & $\begin{array}{c}\text { J ml } \\
\text { Toko } \\
\text { Modern }\end{array}$ \\
\hline 1 & Bangkalan & 28 & 27 \\
2 & Sampang & 26 & 19 \\
3 & Pamekasan & 16 & 14 \\
4 & Sumenep & 36 & 15 \\
\hline J umlah & $\mathbf{1 0 6}$ & $\mathbf{7 5}$ \\
\hline
\end{tabular}

Hasil pengamatan tersebut memberikan penjelasan bahwa pasar tradisional perlu mendapatkan perlindungan. Perlindungan menjadi penting karena perlindungan ditujukan kepada pihak yang melekat kelemahan-kelemahan, karena faktor sosial, ekonomi, maupun politik. Perlindungan hukum dimaksudkan agar kelemahan tersebut tidak dimanfaatkan atau dijadikan lahan eksploitasi pihak lain.

Pembangunan jembatan suramadu membawa dampak berupa kelancaran transportasi, sehingga merangsang bagi investor untuk menanamkan investasi mereka, tidak terkecuali pengelola toko modern. Berdasarkan pengamatan, terjadi peningkatan jumlah toko modern setelah adanya pembangunan Suramadu dan bahkan bisa meningkat terus pada tahun mendatang. Hal ini didasari fakta yang ditunjukkan oleh toko modern yang memberikan kenyamanan dan perbaikan dalam memberikan pelayanannya kepada para pembeli. Beberapa perbedaan yang ditampilkan oleh toko modern dengan pasar tradisional sebagaimana tabel verikut.

\section{Tabel 2 : Perbandingan Pasar Tradisional dan Toko Modern}

\begin{tabular}{|c|c|c|}
\hline No & Pasar tradisional & Toko modern \\
\hline 1 & $\begin{array}{l}\text { Harga bisa ditawar, } \\
\text { harga tergantung pa } \\
\text { da kesepakatan pen- } \\
\text { jual dengan pembeli }\end{array}$ & $\begin{array}{l}\text { Konsumen tidak dapat } \\
\text { menawar harga kare- } \\
\text { na terdapat label har- } \\
\text { ga khusus pada barang } \\
\text { yang dijual (barcode) }\end{array}$ \\
\hline 2 & $\begin{array}{l}\text { Barang yang dijual } \\
\text { lebih mencirikan ko- } \\
\text { moditi lokal }\end{array}$ & $\begin{array}{l}\text { Barang yang dijual le- } \\
\text { bih variatif }\end{array}$ \\
\hline 3 & $\begin{array}{l}\text { Penjual layani pem- } \\
\text { beli sehingga konsu- } \\
\text { men kurang bebas } \\
\text { dalam memilih ba- } \\
\text { rang }\end{array}$ & $\begin{array}{l}\text { Konsumen memilih \& } \\
\text { mengambil sendiri ba- } \\
\text { rang yang hendak di- } \\
\text { beli (swalayan) }\end{array}$ \\
\hline 4 & $\begin{array}{l}\text { Kenyamanan dan ke- } \\
\text { bersihan berbelanja } \\
\text { kurang }\end{array}$ & $\begin{array}{l}\text { Kenyamanan toko men } \\
\text { jadi pertimbangan khu } \\
\text { sus bagi konsumen da- } \\
\text { lam memilih di toko } \\
\text { mana ia akan berbe- } \\
\text { lanja }\end{array}$ \\
\hline 5 & $\begin{array}{l}\text { Penataan barang ku- } \\
\text { rang menarik }\end{array}$ & $\begin{array}{l}\text { Barang yang dijual di- } \\
\text { pajang (display) }\end{array}$ \\
\hline 6 & $\begin{array}{l}\text { Waktu pelayanan ter } \\
\text { batas }\end{array}$ & $\begin{array}{l}\text { Waktu pelayanan le- } \\
\text { bih lama sampai pukul } \\
23.00\end{array}$ \\
\hline 7 & $\begin{array}{l}\text { Pembayaran umum- } \\
\text { nya dilakukan secara } \\
\text { tunai }\end{array}$ & $\begin{array}{l}\text { Pembayaran umumnya } \\
\text { dapat dilakukan seca- } \\
\text { ra tunai dan kredit. }\end{array}$ \\
\hline 8 & $\begin{array}{l}\text { Manajemennya ku- } \\
\text { rang teratur }\end{array}$ & $\begin{array}{l}\text { Pengelola umumnya } \\
\text { berbentuk badan usa- } \\
\text { ha dengan manajemen } \\
\text { yang teratur }\end{array}$ \\
\hline
\end{tabular}

Sumber: data primer diolah, 2011

Pengertian pasar tradisional dan toko modern menurut Pasal 1 angka 2 dan angka 5 Perpres No. 112 Tahun 2007, adalah sebagai berikut

Pasar tradisional adalah pasar yang dibangun dan dikelola oleh Pemerintah, Pemerintah Daerah, Swasta, Badan Usaha Milik Negara dan Badan Usaha Milik Daerah termasuk kerjasama dengan swasta dengan tempat usaha berupa toko, kios, los dan tenda yang dimiliki/ dikelola oleh pedagang kecil, menengah, swadaya masyarakat atau koperasi dengan usaha skala kecil, modal kecil dan dengan proses jual beli barang dagang melalui tawar menawar. Toko modern adalah toko dengan sistem pelayanan mandiri, menjual berbagai jenis barang secara eceran yang ber-bentuk minimarket, supermarket, department store, hypermarket, ataupun grosir yang berbentuk perkulakan. 
Toko modern yang ada, diklasifikasi menjadi minimarket, supermarket, hypermarket, department store, perkulakan, di mana pengklasifikasian tersebut didasarkan pada batasan luas lantai penjualan yang digunakan ${ }^{6}$. Batasan tersebut secara tidak langsung menunjukkan skala usaha masing-masing. Pasal 9 Permendag No. 53/ M-DAG/ PER/ 12/ 2008 (selanjutnya disingkat: Permendag No. 53 Tahun 2008) mengatur mengenai batasan luas lantai penjual toko modern sebagai berikut:

a. Minimarket, kurang dari $400 \mathrm{~m}^{2}$ (empat ratus meter persegi);

b. Supermarket, $400 \mathrm{~m}^{2}$ (empat ratus meter persegi) sampai dengan 5.000 $\mathrm{m}^{2}$ (lima ribu meter persegi);

c. Hypermarket, lebih dari $5.000 \mathrm{~m}^{2}$ (lima ribu meter persegi);

d. Department store, lebih dari $400 \mathrm{~m}^{2}$ (empat ratus meter persegi); dan

e. Perkulakan, lebih dari $5.000 \mathrm{~m}^{2}$ (lima ribu meter persegi)

Berdasarkan hasil pengamatan, dengan mendasarkan pada klasifikasi tersebut, di Madura, toko modern yang dominan ialah berjenis minimarket (Indomaret, Alfamart) yaitu sebanyak 70 gerai, sedangkan berjenis supermarket sebanyak 5 gerai, adapun yang berjenis hypermarket, dan department store belum ada. Informan pada dasarnya memberikan penjelasan. Banyaknya pendirian minimarket di Madura disebabkan prosedur pendiriannya mudah, serta tidak dipersyaratkan adanya analisis kondisi sosial ekonomi masyarakat sebagaimana toko modern lainnya.

Berdasarkan studi dokumen, terungkap bahwa kemudahan prosedur pendirian itu difasilitasi oleh regulasi yang tertuang dalam Permendagri No. 53 Tahun 2008 yang memberikan pengecualian persyaratan analisis kondisi sosial ekonomi masyarakat bagi pendirian minimarket, sebagaimana diatur dalam Pasal 3. Permendagri No. 53 Tahun 2008 juga memberikan batasan jenis-jenis toko modern yang dapat dimasuki oleh penanam modal dalam ne-

\footnotetext{
M. Udin Silalahi, "Persaingan Di Industri Ritel Ditinjau dari Aspek Hukum Persaingan Usaha", J urnal Hukum Bisnis, Vol. 27 No. 1, Tahun 2008, Jakarta: Fakultas Hukum Unika Atma Jaya, hlm. 7.
}

geri $100 \%$ yaitu meliputi: pertama, minimarket dengan luas lantai penjualan kurang dari 400 $\mathrm{m}^{2}$ (empat ratus meter persegi); kedua, Supermarket dengan luas lantai penjualan kurang dari $1.200 \mathrm{~m}^{2}$ (seribu dua ratus meter persegi); dan ketiga Department Store dengan luas Iantai penjualan kurang dari $2.000 \mathrm{~m}^{2}$ (dua ribu meter persegi). Dengan demikian, selebihnya penanam modal asing dapat mengikuti kompetisi baik dalam pendirian supermarket di atas 1.200 $\mathrm{m}^{2}$, department store lebih dari $2000 \mathrm{~m} 2$, hypermarket dan perkulakan. Kondisi ini, padahal apabila dianalisis lebih mendalam, sebenarnya pengaturan toko modern tidak cukup hanya pada pembatasan luas lantai saja, tetapi sebenarnya yang paling mendasar adalah barang atau komoditas apa saja yang diperbolehkan untuk dijual di dalam supermarket maupun hypermarket tersebut. Hal ini penting, apabila sampai barang-barang pertanian yang segar juga dijual di supermarket, akibatnya karena skala ekonominya beda maka tentu pasar tradisional akan menjadi korban dari kompetisi yang tidak seimbang tersebut.

\section{Faktor-faktor yang Menjadi Pendorong dan Penghambat Kompetisi antara Pasar Tradisi- onal dengan Toko Modern}

Berdasarkan studi dokumen terhadap Pasal 12 Perpres No.112 Tahun 2007, Izin Usaha Toko Modern (IUTM) merupakan syarat untuk mendirikan toko modern (minimarket, supermarket, department store, hypermarket dan perkulakan). IUTM tersebut harus dilengkapi dengan studi kelayakan termasuk analisis mengenai dampak lingkungan (AMDAL) terutama aspek sosial budaya dan dampaknya bagi pelaku pedagang eceran setempat dan rencana Kemitraan dengan Usaha kecil (Pasal 13 Perpres No. 112 Tahun 2007). Namun, ketentuan tersebut diperlunak Permendagri, yang mengatur bahwa untuk pendirian minimarket, tidak diperlukan AMDAL sebagaimana yang diwajibkan bagi pendirian toko modern lainnya (Pasal 3 Permendag No. 53 Tahun 2008). ${ }^{7}$ Pengecualian persyaratan

Bandingkan dengan Weda Kupita dan Rahadi Wasi Bintoro, "Implementasi Kebijakan Zonasi Pasar Tradisional dan Pasar Modern (Studi Di Kabupaten Pur- 
AMDAL bagi pendirian minimarket merupakan salah satu faktor menjamurnya minimarket di Madura, sehingga kompetisi antara pasar tradisional dengan toko modern semakin meningkat. Perbedaan kedua peraturan perundangan tersebut dapat dijelaskan pada tabel berikut:

\section{Tabel 3 : Perbedaan Persyaratan Pendirian Toko Modern}

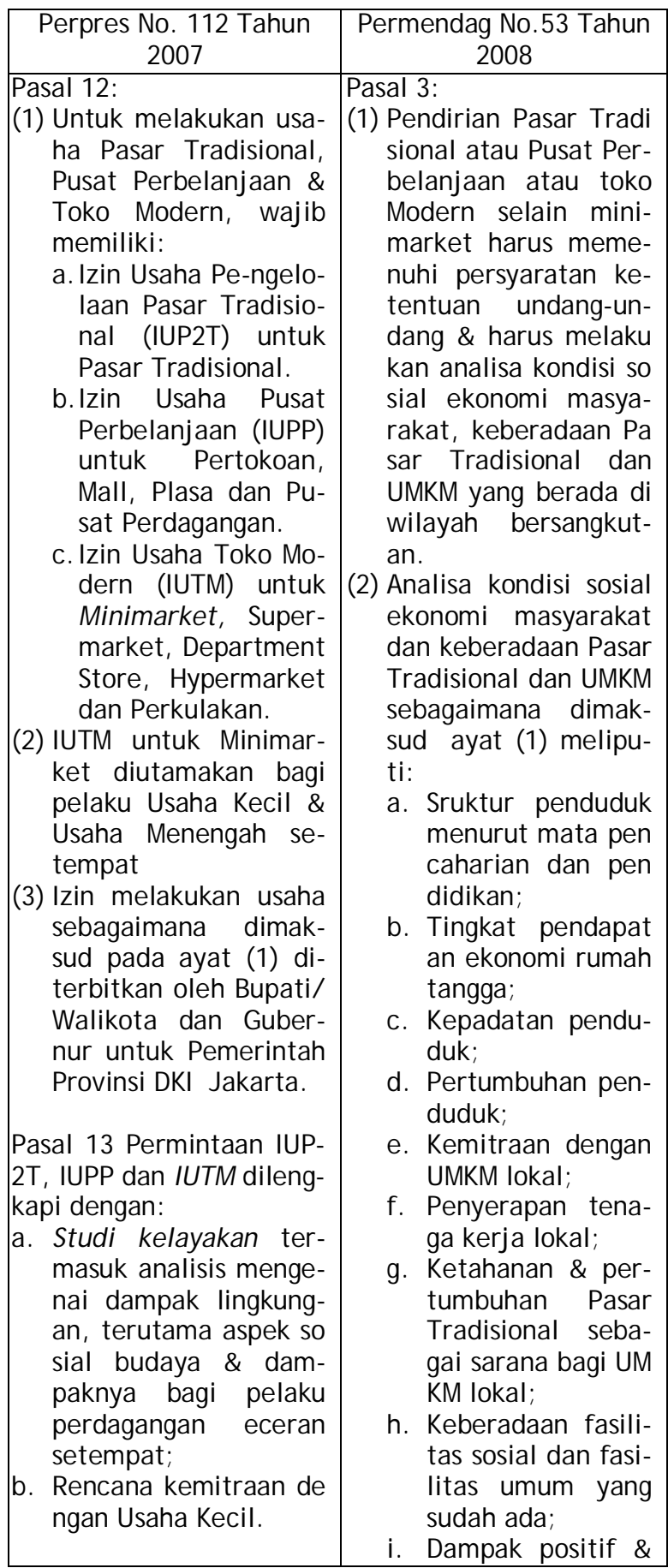

balingga)", J urnal Dinamika Hukum, Vol 12 No. 1, Januari 2012, hlm. 53.

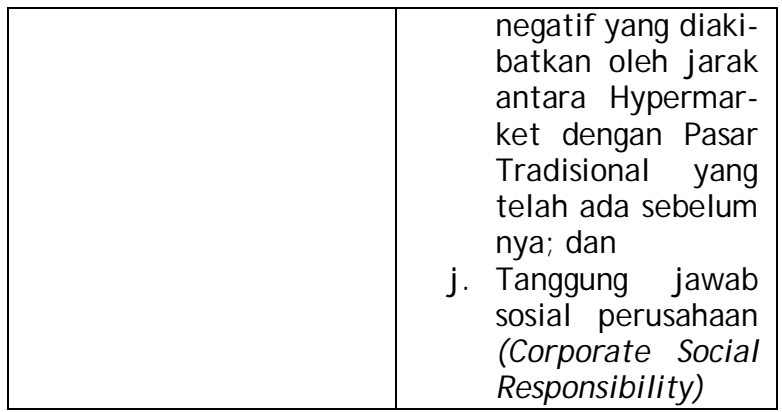

Kemudahan tersebut dapat dipandang sebagai bentuk keberpihakan regulasi pada peritel kuat daripada penerapan semangat keadilan sosial sebagaimana amanat UUD NRI 1945. AMDAL adalah analisis mengenai dampak lingkungan terutama aspek sosial budaya dan dampaknya bagi pelaku pedagang eceran setempat. Tidak adanya persyaratan AMDAL dalam pendirian minimarket semakin memberi tempat pada peritel-peritel kuat (Indomaret dan Alfamart) untuk menguasai pasar ritel di Madura.

Pendirian toko modern di Madura masih menerapkan model SIUP sebagai prosedur perizinan, karena pengajuan permohonan ij in dilakukan sebelum munculnya regulasi tersebut. Hal yang membedakan penggunaan SIUP dengan IUTM adalah adanya persyaratan AMDAL tersebut. Setelah tahun 2008, belum ada toko modern yang mengajukan permohonan ijin, kalaupun ada yang mendirikan minimarket, hanya mengajukan permohonan tanda daftar perusahaan (TDP) seperti Indomaret dan Alfamart karena mereka telah mempunyai SIUP Pusat. ${ }^{8}$ Berdasarkan wawancara mendalam, diketahui bahwa belum diterapkannya IUTM disebabkan karena sampai saat ini belum ada contoh rincian materi penyusunan analisis kondisi sosial ekonomi masyarakat tersebut. ${ }^{9}$ Bagi kantor cabang perusahaan ataupun kantor perwakilan perusahaan tidak memerlukan permohonan SIUP Iagi karena sudah ada SIUP kantor pusatnya sebagaimana PT Indomaret dan PT Alfamart. Hal tersebut sesuai dengan keten-tuan Pasal 4 ayat (1) Pemendag No.36/M-DAG/ PER/ 9/2007

8 Hasil wawancara dengan Khairul Saleh, Kepala Kantor Pelayanan Perijinan dan Penanaman Modal (KP3M) Sampang, tanggal 27 September 2011.

9 Hasil wawancara dengan RM. Ilyas Santoso, SE, Kabid Perdagangan Disperindag Kabupaten Bangkalan, tanggal 12 J uli 2011. 
tentang Penerbitan Surat Ijin Usaha Perdagangan (SIUP) (selanjutnya disebut Permendagri No. 36 Tahun 2007) selengkapnya merumuskan sebagai berikut:

(1) Kewajiban memiliki SIUP sebagai dimaksud Pasal 2 ayat (1) dikecualikan terhadap:

a. Kantor Cabang Perusahaan atau Kantor Perwakilan Perusahaan;

b. Perusahaan Kecil perorangan yang tidak berbentuk Badan Hukum atau Persekutuan yang diurus, di jalankan atau dikelola sendiri oleh pemiliknya atau anggota keluarga kerabat terdekat;

c. Pedagang Keliling, Pedagang Asongan, Pedagang Pinggir J alan atau Pedagang Kaki Lima.

(2) Perusahaan sebagaimana dimaksud pada ayat (1) huf b dan huruf $c$ dapat diberikan SIUP apabila dikehendaki yang bersangkutan.

Berdasarkan studi dokumen yang dilakukan, terdapat perbedaan pengaturan antara Perpres No. 112 Tahun 2007 dengan Permendagri No. 53 Tahun 2008 khususnya tentang ketentuan jarak pendirian minimarket. Perpres telah mengatur bahwa dalam pendirian toko modern (minimarket, supermarket, department store, hypermarket) waj ib memperhatikan jarak pendirian hypermarket dengan pasar tradisional yang ada sebelumnya (Pasal 4). Namun karena minimarket telah dikecualikan oleh Permendag No.53 Tahun 2008 terkait dengan AMDAl, berarti sekaligus juga memberikan pengecualian dalam arti minimarket dapat tidak memperhatikan atau boleh mengabaikan keberadaan pasar tradisional dan UMKM yang berada di wilayah bersangkutan. Tidak adanya pengaturan pembatasan jarak antara minimarket dengan pasar tradisional semakin mendesak pedagang pasar tradisional dan toko tradisional khususnya dalam bentuk menurunnya omset penjualan. Hal ini apabila dibiarkan terus menerus tanpa ada pengaturan tentu jangka panjang akan dapat memarjinalkan, bahkan mematikan pasar tradisional di wilayah tersebut.

Berdasarkan wawancara mendalam dengan pejabat terkait diketahui ternyata terdapat perbedaan sikap pemerintah kabupaten/ kota di Madura dalam menghadapi pe-ningkatan minat pendirian toko modern, ada yang terbuka (Bangkalan dan Sumenep) dan ada yang terbuka dengan syarat (Sampang dan Pamekasan). Sejak pembangunan jembatan Suramadu, di Bangkalan terjadi peningkatan jumlah toko Indomaret, semula 2 gerai terjadi penambahan 12 gerai sehingga berjumlah 14 gerai, di mana Indomaret menyebar di 9 dari 18 kecamatan yaitu Kamal 2 gerai, Bangkalan 5 gerai, Kwanyar, Tanah Merah, Klampis, Sepulu, Tanjung Bumi, Arosbaya, dan Blega masing-masing 1 gerai. Di Sumenep, meskipun terbuka, penambahan Indomaret tidak berbanding lurus dengan jumlah kecamatan disebabkan wilayah pemukiman penduduk di Sumenep bersifat memencar sehingga kurang diminati oleh Indomaret. penambahan 5 gerai di Sumenep yang menyebar di Kecamatan-kecamatan Kota 2 gerai, Lenteng, Kalianget, dan Prenduan masing-masing 1 gerai. Wakil Bupati (Wabup) Pamekasan menghimbau agar pembukaan toko modern hanya di kecamatan kota, sehingga terjadi penambahan 5 gerai Indomaret di Pamekasan, semuanya berada di kecamatan kota. Hal ini dilakukan dalam rangka menjaga kelangsungan pasar dan toko tradisional karena bagi masyarakat apabila ter-dapat selisih harga, mereka akan memilih yang lebih murah walaupun agak jauh. Pada saat Indomaret mengajukan permohonan pendaftaran 2 gerai untuk masing-masing kecamatan, tidak dikabulkan karena adanya himbauan Wabup tersebut. ${ }^{10}$ Pada tahun 2011, di Sampang terjadi penangguhan permohonan 6 TDP toko modern dengan alasan sampai dikeluarkannya legislasi daerah tentang penataan toko modern. ${ }^{11}$

Perbedaan sikap tersebut jika ditelusuri bermuara dari pemilihan paradigma pembangu-

10 Hasil wawancara mendalam dengan Drs. R. Harry Sucahyono, MM, Kasi Pendaftaran Perdagangan Disperindag Kab. Pamekasan,tanggal 19 September 2011. Adanya himbauan Wabup ini memunculkan ekses, di Kecamatan Waru, Indomaret yang sudah menyewa (kontrak tanah) selama 10 tahun dan sudah bero-perasi, saat mengajukan pendaftaran ditolak, sehingga sampai saat ini statusnya tidak jelas (beroperasi tanpa pendaftaran dan terjadi pembiaran).

11 Hasil wawancara mendalam dengan Khairul Saleh, Kepala Kantor Pelayanan Perijinan dan Penanaman Modal (KP3M) Sampang, tanggal 27 September 2011. 
nan yang diyakini benar oleh para pengambil kebijakan. Bagi pihak yang meyakini paradigma pembangunan ekonomi lebih berorientasi pada perkembangan ekonomi cenderung mendukung upaya pemberian keleluasaan bagi pendirian toko modern karena menunjang perkembangan ekonomi daerah yang pangkalnya dapat meningkatkan pendapatan asli daerah (PAD), sedangkan bagi pihak yang meyakini paradigma pembangunan ekonomi yang berorientasi pada "keadilan sosial", tentunya perkembangan ekonomi yang diharapkan adalah perkembangan dan kemajuan dalam konteks kesatuan ekonomi yang berkeadilan bagi seluruh masyarakat Indonesia.

Tujuan UU Anti Monopoli adalah terciptanya efisiensi dalam berusaha, namun perkembangan ekonomi yang efisien adalah efisiensi yang berkeadilan bukan efisiensi sebagaimana pengertian efisiensi murni seperti dianut oleh negara-negara kapitalis ${ }^{12}$. Efisiensi ini mengakibatkan pedagang dapat memenangkan kompetisi dan dapat berkembang menjadi perusahaan-perusahaan besar, UUD 1945 sangat konsisten dengan prinsip efisiensi berkeadilan, ${ }^{13}$ sehingga tersingkirnya pasar tradisional dan pelaku usahanya disebabkan adanya persaingan yang tidak seimbang adalah sangat tidak adil. ${ }^{14}$

Berdasarkan pengamatan, pada aspek manajemen, yang meliputi waktu layanan, kebersihan dan kenyamanan, merupakan faktor yang mempengaruhi kompetisi. Secara umum, waktu layanan pasar tradisional rata-rata sampai pukul 11.00 WIB kecuali kecamatan Kota maksimal pukul 16.00 WIB. Pasar tradisional di Madura dikenal hari pasaran, yaitu hari ditawarkannya produk yang lengkap yaitu hari-hari tertentu, 1 hari/minggu sampai 3 hari/minggu, sedangkan toko modern, waktu layanannya

12 lihat Sutan Remy Sjahdeini, "Larangan Praktik Monopoli dan Persaingan Usaha Tidak Sehat", Jurnal Hukum Bisnis, Edisi 10, Tahun 2000, Jakarta: Fakultas Hukum Unika Atma Jaya hlm. 6.

13 Jimat Jojiyon Suhara, "Urgensi Redefinisi Asas dan Tujuan UU No 5/1999 Sebagai Dasar Hukum dan Kebijakan Persaingan Usaha Di Indonesia", J urnal Persaingan Usaha, Edisi I, Tahun 2009, Jakarta: KPPU, hlm. 93.

14 Ibid., hlm. 102. setiap hari dan lebih panjang, di mana Layanan sampai pukul 22.00 WIB. Harga yang ditawarkan toko modern relatif sama dengan pasar tradisional, namun demikian produk yang ditawarkan lebih lengkap, serta ditambah kenyamanan dan kebersihan, sehingga semakin menempatkan pasar tradisional pada posisi dan kondisi yang tidak seimbang. Dalam rangka mengantisipasi kompetisi tersebut, seharusnya pendirian pasar tradisional, pusat perbelanjaan dan toko modern mengacu pada RTRW Kabupaten/ Kota dan Rencana Detail Tata Ruang Wilayah Kabupaten/ Kota termasuk peraturan zonasinya (Pasal 2 ayat (1) Perpres 112 Tahun 2007). Namun, sampai akhir tahun 2011, dari 4 (empat) kabupaten di Madura, hanya Bangkalan yang sudah memiliki Perda RT RW, sudah ada ketentuan tentang arahan zonasi kawasan perdagangan dan jasa yaitu Perda No. 10 Tahun 2009 tentang Rencana Tata Ruang Wilayah Kabupaten Bangkalan Tahun 2009-2029 (selanjutnya disebut Perda RTRW Bangkalan). Tersedianya Perda RTRW tidak serta merta mengindikasikan penataan pasar tradisional dan toko modern lebih baik, karena ada fakta telah terjadi pemindahan (relokasi) pasar tradisional Ki Lemah Duwur, dulunya berlokasi di dalam kota yang dekat pemukiman penduduk, namun sekarang dipindahkan ke lokasi yang jauh dari pemukiman penduduk dan berdekatan, serta bersebelahan dengan bangunan yang rencananya bernama "Bangkalan Plasa".

Perda RTRW Bangkalan mengatur mengenai zonasi kawasan perdagangan dan jasa ditetapkan dengan memperhatikan ketentuan jarak pendirian pasar modern atau toko modern terhadap pasar tradisional dengan radius 1 km (Pasal 104 huruf g Perda RTRW Bangkalan). Namun, rupanya saat terjadinya pemin-dahan lokasi pasar tradisional Ki Lemah Duwur Bangkalan tidak memperhatikan ketentuan tersebut. Kondisi demikian bukan hanya bertentangan dengan Perda RTRW, tetapi juga membawa implikasi bahwa apabila pusat perbelanjaan tersebut beroperasi, hal yang tidak bisa dihindari adalah terjadinya pemangsaan sebagian konsumen pasar tradisional oleh toko modern. Pada akhirnya pasar tradisional semakin ter- 
marjinalkan, sesuai dengan logika kompetisi yakni "zero sum game" yang kuat akan tetap bertahan dan yang lemah akan menghilang.

\section{Upaya yang Dilakukan dalam Rangka Meng- atasi Kendala Kompetisi}

Pemerintah Kabupaten (Pemkab) memiliki Unit Pelaksana Teknis Dinas (UPTD) Pasar sebagai pihak yang bertanggung jawab atas pembinaan dan pengelolaan pasar tradisional di wilayahnya. Berbagai upaya telah dilakukan mulai dari renovasi bangunan maupun peningkatan sarana dan prasarana. Namun, peran Pemkab sebagai pengelola pasar baru memposisikan pasar tradisonal sebagai potensi sumber pendapatan asli daerah (PAD) dan belum menyertainya dengan pengelolaan pasar yang professional. ${ }^{15}$

Unit Pelaksana Teknis Dinas (UPTD) Pasar masing-masing kabupaten dalam rangka meningkatkan kompetisi dengan toko modern, telah melakukan peningkatan sarana dan prasarana pasar tradisional. Berdasarkan wawancara mendalam, diperoleh data bahwa di Pamekasan, pada 2011 telah dilakukan pavingisasi di Pasar Lenteng dan Pusat Pasar "Shopping". Pada 2012, direncanakan untuk renovasi Pasar 17 Agustus Pamekasan, bahkan apabila permintaan pedagang untuk berjualan di Pasar Kolpajung semakin meningkat, rencana pembangunan pasar Kolpajung menjadi 2 lantai saat mendatang tidak dapat dihindari lagi. ${ }^{16}$ Peningkatan tersebut sebagai fakta bahwa pasar tradisional merupakan tempat penampungan tenaga kerja yang tidak terserap di sektor lain. Pada tahun 2011 di Sumenep mulai dilakukan pembangunan Pasar Anom 2 lantai sekaligus sebagai upaya perbaikan akibat sebagian terbakar tahun 2007, kemudian pada tahun 2012 direncanakan pembenahan terhadap 7 pasar tradisional yang dananya berasal dari Anggaran Pendapatan dan Belanja Daerah (APBD) dan Dana Alokasi Khu-

15 Anonim, "Analisis Keberlanjutan Pasar Tradisional Dalam Iklim Persaingan Usaha Yang Dinamis Di Kota Bandung", Sosio Humaniora, Vol 10 No. 2, Juli 2008, Bandung: Unpad.

16 Hasil wawancara mendalam dengan Sudiono, Kabid Pendapatan Dispenda Pamekasan, tanggal 14 Oktober 2011. sus (DAK). ${ }^{17}$ Sementara itu, pada tahun $2011 \mathrm{di}$ Sampang telah dilakukan pembenahan 47 kios Pasar Omben dan pada tahun 2012 direncanakan pembenahan 11 pasar berupa pavingisasi jalan, pengerasan, perbaikan selokan, perbaikan los, toilet dan lahan parkir. ${ }^{18}$ Upaya relokasi dan renovasi pasar tradisional menjadi semi modern juga terjadi di pasar Ki Lemah Duwur Bangkalan yang lokasinya bersebelahan dengan pusat perbelanjaan.

Tugas khusus Kementerian Perdagangan terhadap pasar tradisional adalah pada kebijakan pembinaan dan pengawasan. Pembinaan berupa penciptaan sistem manajemen pengeIolaan pasar, pelatihan terhadap sumberdaya manusia (SDM), konsultasi, fasilitasi kerjasama, pembangunan dan perbaikan sarana maupun prasarana pasar, sedangkan pengawasan adalah pengawasan terhadap pengelolaan usaha pasar tradisinal, pusat perbelanjaan dan toko modern (Pasal 18 dan Pasal 19 Permendagri No. 53 Tahun 2008).

Ketentuan Pasal 10 Permendagri No. 53 Tahun 2008 mengatur bahwa bagi pelaku usa-ha yang akan melakukan kegiatan usaha di bidang pasar tradisional, pusat perbelanjaan dan toko modern, diwajibkan memiliki: pertama, IUP2T untuk Pasar Tradisional; kedua, UPP untuk Pertokoan, Mall, Plasa dan Pusat Perdagangan; ketiga, IUTM untuk Minimarket, Supermarket, Department Store, Hypermarket dan Perkulakan.

Berdasarkan studi dokumen, diketahui bahwa pendirian minimarket selain harus memiliki ijin, juga harus memperhatikan kepadatan penduduk, perkembangan pemukiman baru, aksebilitas wilayah (arus lalu lintas), dukungan/ ketersediaan infrastruktur serta memperhatikan keberadaan pasar tradisional dan warung/ toko di wilayah sekitar yang lebih kecil daripada minimarket tersebut. Pendirian minimarket diutamakan untuk diberikan kepada pelaku usaha yang domisilinya sesuai dengan lokasi minimarket dimaksud (Pasal 9 jo Pasal 10 Permen-

\footnotetext{
17 Hasil wawancara mendalam dengan Imam Sukandi, Kabid Pendapatan Dispenda Sumenep, tanggal 3 Oktober 2011.

18 Hasil wawancara mendalam dengan Drs. Damanhuri, Kasi Pasar Bidang Pendapatan Dispenda Sampang, tanggal 18 Oktober 2011.
} 
dagri No. 53 Tahun 2008). Lokasi pendirian pasar tradisional, pusat perbelanjaan dan toko modern wajib mengacu pada Rencana Tata Ruang Wilayah Kabupaten/Kota dan Rencana Detail Tata Ruang wilayah Kabupaten/ Kota termasuk peraturan zonasinya. Bagi Kabupaten/ Kota yang belum memiliki Rencana Tata Ruang Wilayah Kabupaten/Kota dan Rencana Detail Tata Ruang Wilayah Kabupaten/Kota tidak diperbolehkan memberi izin lokasi untuk pembangunan Pasar Tradisional, Pusat Perbelanjaan dan Toko Modern (Pasal 2 Permendagri No. 53 Tahun 2008).

Persoalannya sampai saat ini, 4 (empat) kabupaten di Madura belum memiliki peraturan daerah yang mengatur tentang penataan dan perlindungan pasar tradisional. Peraturan yang ada hanya bersifat bagaimana pasar tradisional dikelola sebagai sumber PAD melalui peningkatan penarikan retribusi, seperti Perda Kabupaten Bangkalan No.19 Tahun 2008 tentang Penataan, Pengelolaan Pasar dan Retribusi Pasar Daerah, Perda Kabupaten Sampang No. 5 Tahun 2011 tentang Retribusi J asa Umum, sementara di Sumenep, Perda yang mengatur tentang retribusi pasar tertuang dalam Perda tentang J asa Usaha, di mana saat penelitian berlangsung, Perda sedang dalam proses pengundangan dalam lembaran daerah, sehingga belum dapat disebutkan nomor dan tahunnya, di Pamekasan hal tersebut juga sedang dalam proses pembahasan. Bagi peda-gang pasar tradisional, berbagai upaya renovasi maupun relokasi yang dilakukan, pangkalnya adalah meningkatnya harga sewa kios dan los sehingga semakin memperkecil pendapatan mereka. Hal ini mengakibatkan tidak sedikit kios-kios di pasar tradisional yang telah direnovasi masih banyak yang kosong seperti yang terjadi di Pasar Srimangunan Sampang.

Belum adanya legislasi daerah tentang penataan pasar tradisional dan toko modern membawa implikasi pada belum dapat diterapkannya sekaligus ditegakkannya ketentuan Permendagri No. 53 Tahun 2008 khususnya tentang persyaratan AMDAL dalam pendirian toko modern. Belum adanya ketentuan hukum yang mengatur, tidak menghilangkan keyakinan bagi pembina dan pengawas pasar tradisional pada "hukum ekonomi" yang mengandung proposisi bahwa terdapat hubungan terbalik antara penawaran dengan harga, dalam arti semakin banyak penawaran semakin rendah harganya. Menjamurnya toko modern di Madura diharapkan terjadi kompetisi, sehingga harga menjadi murah dan konsumen diuntungkan. Menjamurnya toko modern memang menguntungkan konsumen, tetapi tidak demikian halnya dengan kepentingan pasar tradisional. Tidak adanya sinkronisasi Permendagri dengan Perpres khususnya tentang persyaratan AMDAL bagi pendirian minimarket, menunjukkan perbedaan penggunaan "asas keseimbangan kepentingan pelaku usaha dengan kepentingan umum termasuk kepentingan konsumen" sebagaimana diatur daIam ketentuan Pasal 2 UU Anti Monopoli sebagai landasan pemilihan prioritas antara perkembangan ekonomi dengan perlindungan pasar tradisional. Menurut Suhara, asas keseimbangan dalam Pasal 2 UU Anti Monopoli berbeda dengan fokus Pasal 33 ayat (4) UUD NRI 1945 yang menekankan keseimbangan pada kemajuan dan kesatuan ekonomi nasional. Perbedaan ini sangat signifikan karena pengertian keseimbangan pelaku usaha dengan kepentingan umum sangat kabur, sehingga menyebabkan banyak yang menafsirkan asas atau prinsip dasar UU Anti Monopoli dengan UU Antitrust Amerika ${ }^{19}$.

Sebagian Pemkab melakukan upaya pembatasan pendirian toko modern dalam rangka mendorong kompetisi antara pasar tradisional dengan toko modern, sebagaimana yang dilakukan Pemkab Sampang dan Pamekasan, sedangkan sebagian yang lain memberikan keleluasaan pendirian toko modern sebagaimana Pemkab Bangkalan dan Sumenep. Sikap pemberian keleluasaan tersebut tidak lain sebagai wujud penerapan asas "kesempatan berusaha yang sama" dalam UU Anti Monopoli sehingga pasar tradisional harus berhadapan dengan toko modern. Persoalannya, ketika pasar tradisional harus berkompetisi dengan toko modern dengan posisi status, modal, manajemen yang tidak seimbang, apabila dibiarkan bersaing secara be-

\footnotetext{
${ }^{19}$ J imat J ojiyon Suhara, op. cit, hlm. 102.
} 
bas tanpa campur tangan pemerintah, maka distorsi dan eksploitasi oleh pihak yang kuat terhadap pihak yang lemah tidak dapat dihindari. Pasar tradisional dengan karakteristik lemah modal, lemah manajemen pada akhirnya akan menanggung kekalahan dalam kompetisi.

Berdasarkan teori keadilan John Rawls, setiap orang yang masuk ke dalam pasar dengan bakat dan kemampuan yang alamiah yang berbeda-beda, peluang sama yang dibiarkan pasar tidak akan menguntungkan semua peserta. Keadaan itu akan menimbulkan distribusi yang tidak adil atas kebutuhan-kebutuhan hidup, justru karena perbedaan bakat dan kondisi-kondisi sosial yang kebetulan tadi, apabila kondisi sosial yang kebetulan tadi diperbaiki sehingga sama bagi semua orang, namun tidak berarti bahwa pasar bebas dengan sendirinya akan mendistribusikan kekayaan ekonomi secara sama, justru sebaliknya, terlepas dari perbaikan kondisi sosial yang ada, pasar bebas akan melahirkan kepincangan-kepincangan karena perbedaan bakat dan kemampuan alamiah antara orang yang satu dengan orang yang lainnya. Oleh karena itu, Rawls berpan-dangan bahwa pasar adalah justru merupakan pranata ekonomi yang tidak adil. ${ }^{20}$ Menurut Rawls, sistem sosial harus diatur sedemikian rupa, sehingga distribusi yang dihasilkannya adil apapun yang terjadi. Dalam rangka mewujudkan tujuan ini, proses sosial dan ekonomi perlu diatur dalam lingkungan pranata politik dan hukum yang sesuai. Tanpa pengaturan pranata-pranata latar belakang tersebut secara tepat hasil proses distribusi ini akan tidak adil. Adanya situasi ketidaksamaan mengakibatkan hukum (negara) harus memberikan keuntungan dalam arti memberikan perlindungan kepada golongan masyarakat yang paling kurang beruntung (pasar tradisional), sehingga terwujud keadilan secara sosial ekonomi dalam masyarakat.

Berdasarkan hal tersebut, keberadaan toko modern seharusnya memperhitungkan rasio jumlah dengan struktur penduduk serta ketahanan dan pertumbuhan pasar tradisional. Hal

20 Sonny Keraf, 1996, Pasar Bebas, Keadilan \& Peran Pemerintah, Telaah atas Etika Politik Ekonomi Adam Smith, Yogyakarta: Kanisius, hlm. 264. ini dilakukan dalam rangka menjaga keseimbangan kepentingan, bukan hanya kepentingan toko modern dengan konsumen, tetapi juga keseimbangan kepentingan dan kemajuan dalam kesatuan ekonomi. Kehadiran legislasi daerah tentang penataan toko modern dan pasar tradisional menjadi sangat urgen, khususnya terkait dengan penetapan lokasi dan jumlah, pembatasan jam buka, pembagian produk yang dijual, dan pengaturan perijinan toko modern. Semuanya dilakukan dalam rangka memberikan perlindungan dan kepastian hukum bagi kompetisi pasar tradisional dengan toko modern, karena Satuan Polisi Pamong Praja (Satpol PP) hanya berwenang menegakkan Perda dan tidak berwenang menegakkan Perpres maupun Permendag.

Pada tataran yang lebih tinggi, problema yang muncul dalam praktik hukum, sebenarnya tidak dapat dilepaskan dari kekaburan asas yang menjadi landasan pembentukan UU Anti Monopoli, sehingga sangat urgen untuk menuangkan asas keadilan dan perlindungan dalam UU Anti Monopoli. Terdapat pendapat bahwa asas atau prinsip adalah meta norma yang berarti bahwa asas tidak dirumuskan dalam undang-undang karena hakikat asas adalah meta norma, sehingga asas cukup dituangkan dalam Penjelasan Umum. Namun, ternyata kedudukan Penjelasan Umum masih menimbulkan perdebatan apakah merupakan norma atau bukan. Penulis berpandangan bahwa sudah saatnya asas keadilan dan asas perlindungan dituangkan dalam UU Anti Monopoli, sehingga dapat mengakomodasi kepentingan pasar tradisional serta dapat menghindari perbedaan penafsiran dalam implementasinya. Penerapan asas keadilan dan asas perlindungan dalam UU Anti Monopoli, distorsi dan kesewenang-wenangan pasar dapat dihindari, sehingga tujuan pembentukan UU Anti Monopoli dalam rangka menciptakan kesejahteraan masyarakat dapat dicapai.

\section{Penutup \\ Simpulan}

Kompetisi antara pasar tradisional dengan toko modern pasca Perpres No.112 Tahun 2007 semakin ketat, terbukti dengan mening- 
katnya jumlah toko modern minimarket yang sistem penjualan dan jenis barang yang dijual sama dengan pasar tradisional. Faktor yang menjadi pendorong dan penghambat kompetisi adalah tiadanya legislasi daerah menyebabkan beragamnya sikap pemkab dalam menyikapi permohonan ijin pendirian toko modern di samping aspek manajemen (waktu layanan dan fasilitas) pasar tradisional yang masih belum berorientasi pada manajemen modern juga turut mempengaruhi tingkat kompetisi. Upaya yang telah dilakukan dalam mengatasi kendala kompetisi antara pasar tradisional dengan toko modern melalui peningkatan sarana dan prasarana fisik, namun belum menyentuh pada sisi profesionalitas pengelolaan pasar tradisional.

\section{Saran}

Berdasarkan analisis yang telah dilakukan, penulis merekomendasikan agar segera dibuat Perda tentang penataan dan pembinaan pasar tradisional dan toko modern guna mengatasi kendala kompetisi antara pasar tradisional dan toko modern di Madura. Selain itu, perlu adanya sinkronisasi antara regulasi yang satu dengan regulasi lainnya, sehingga dalam tataran praktis tidak mengalami hambatan dalam pelaksanaa dan perlu peningkatan profesionalitas bagi pihak-pihak yang terkait dalam pengeIolaan pasar tradisional termasuk pedagangnya, sehingga mempunyai kemampuan untuk berdaya saing dan pada masanya nanti mampu memenangkan persaingan/ kompetisi.

\section{Daftar Pustaka}

Anonim. "Analisis Keberlanjutan Pasar Tradisional dalam Iklim Persaingan Usaha yang Dinamis di Kota Bandung". Sosio Humaniora. Vol 10 No. 2. Juli 2008. Bandung: Unpad;
---.--. "Penelitian Dampak Keberadaan Pasar Modern (Supermarket dan Hypermarket) terhadap Usaha Ritel Koperasi/ Waserda dan Pasar Tradisional". J urnal Pengkajian Koperasi dan UKM. Vol. 1 No. 1. Tahun 2006. Jakarta: Deputi Bidang Pengkajian Sumberdaya UKMK;

J usmono, Ali. "Persaingan Usaha Pasar Ritel di In-donesia: Siapa yang menang". Jurnal Hukum Bisnis. Vol. 27 No. 1. Tahun 2008. Jakarta: Fakultas Hukum Unika Atma J aya;

Keraf, Sonny. 1996. Pasar Bebas, Keadilan \& Peran Pemerintah, Telaah atas Etika Politik Ekonomi Adam Smith. Yogyakarta: Kanisius;

Kupita, Weda dan Rahadi Wasi Bintoro. "Implementasi Kebijakan Zonasi Pasar Tradisional dan Pasar Modern (Studi Di Kabupaten Purbalingga)". Jurnal Dinamika Hukum. Vol 12 No. 1, Januari 2012;

Martadisastra, Dedie S. "Persaingan Usaha Ritel Modern dan Dampaknya Terhadap Perdagangan Ritel Tradisional". J urnal Persaingan Usaha. Vol. 4. Tahun 2010. Jakarta: KPPU;

Santosa, Awan \& Puthut Indroyono. 11 Maret. Pedagang Pasar Tradisional Terancam. tersedia di website http:/ www.ekonomirakyat. org/artikel. php?j $d=13$. diakses 11 Nopember 2011;

Silalahi, M Udin. "Persaingan Di Industri Ritel Ditinjau dari Aspek Hukum Persaingan Usaha". J urnal Hukum Bisnis. Vol. 27 No. 1. Tahun 2008. Jakarta: Fakultas Hukum Unika Atma J aya;

Sjahdeini, Sutan Remy. "Larangan Praktik Monopoli dan Persaingan Usaha Tidak Sehat". J urnal Hukum Bisnis. Edisi 10, Tahun 2000, J akarta: Fakultas Hukum Unika Atma J aya;

Suhara, Jimat J ojiyon. "Urgensi Redefinisi Asas dan Tuj uan UU No 5/ 1999 Sebagai Dasar Hukum dan Kebijakan Persaingan Usaha Di Indonesia". Jurnal Persaingan Usaha. Edisi I. Tahun 2009. J akarta: KPPU. 